\title{
Analytical Method Validation and Determination of Free Drug Content of 4-n-Butylresorcinol in Complex Lipid Nanoparticles Using RP-HPLC Method
}

\author{
Rini Dwiastuti ${ }^{1}$, Marchaban², Enade Perdana Istyastono ${ }^{1}$, and Florentinus Dika Octa Riswanto ${ }^{1, *}$ \\ ${ }^{1}$ Faculty of Pharmacy, Universitas Sanata Dharma, Campus 3 Paingan, \\ Maguwoharjo, Depok, Sleman, Yogyakarta 55282, Indonesia \\ ${ }^{2}$ Faculty of Pharmacy, Universitas Gadjah Mada, Yogyakarta 55281, Indonesia
}

Received October 12, 2017; Accepted February 26, 2018

\begin{abstract}
Lipid nanoparticles, one of nanoparticle technology results has been developed both as a drug delivery system and as a research object. Complex lipid nanoparticle, in the drug delivery system development, has an advantage due to its less toxicity. It is important to develop a validated analytical method to determine the drug content in the system of nanoparticle lipid. This research aimed to develop a valid RP-HPLC method to determine free drug content of 4-n-butylresorcinol in the liposome matrix followed by the determination of the encapsulation efficiency (EE\%). A system of the RP-HPLC method has been developed using a column of $C_{18}$ and methanol-redistilled water-glacial acetic acid 79:20:1 ( $/ \mathrm{v}$ ) as the mobile phase with $\mathrm{pH}$ maintained at 2.1-2.6. This method was validated in the parameters of selectivity, sensitivity, linearity, accuracy, and precision. During 30 days of storage, the complex lipid nanoparticle system showed the increase in the EE\% value during storage time.
\end{abstract}

Keywords: 4-n-butylresorcinol; encapsulation efficiency; lipid nanoparticle; validation

\section{ABSTRAK}

Nanopartikel lipid sebagai salah satu hasil teknologi nanopartikel masih terus dikembangkan sebagai sistem penghantaran obat baik sebagai pengobatan maupun dalam lingkup penelitian. Kompleks nanopartikel lipid mempunyai banyak keuntungan diantaranya adalah memiliki toksisitas yang rendah saat digunakan dalam pengobatan. Mengingat kepentingannya, diperlukan suatu metode analisis tervalidasi dalam penetapan zat aktif dalam nanopartikel lipid. Penelitian ini bertujuan untuk mendapatkan validasi metode analisis penentuan obat bebas dalam sistem kompleks nanopartikel lipid dengan ligan senyawa 4-n-butilresorsinol yang digunakan dalam penentuan persen efisiensi enkapsulasi dalam sistem kompleks nanopartikel lipid. Metode yang digunakan dalam validasi metode analisis 4-n-butilresorsinol ini adalah kromatografi cair kinerja tinggi dengan fase diam $C_{18}$ dan fase gerak metanol-air-asam asetat glasial dengan komposisi 79:20:1 ( $/ v$ ) pada $p H$ 2,1-2,6. Hasil yang diperoleh memenuhi semua parameter validasi metode analisis yang dilakukan meliputi selektivitas, sensitivitas, linieritas, akurasi dan presisi. Selama penyimpanan selama 30 hari, dihasilkan peningkatan nilai persen efisiensi enkapsulasi (\%EE) pada sistem kompleks nanopartikel lipid 4-n-butilresorsinol.

Kata Kunci: 4-n-butilresorsinol; efisiensi enkapsulasi; nanopartikel lipid; validasi

\section{INTRODUCTION}

Nanoparticle technology has been developed in drug delivery systems due to its ability to penetrate walls and intercellular space [1]. The nanoparticle technology used in drug delivery systems is a drug system with a carrier matrix such as a nanosphere, nanoemulsion, or nanoliposomes [2]. The definition of nanoparticles varies across several references due to their different size limits. Some papers defined the size of nanoparticles as $<\quad 1 \mu \mathrm{m}$ [1]. The European Commission Recommendations [3] states that "a defined nanomaterial must consist of $50 \%$ or more of particles having sizes between 1-100 nm", and the other source described the size of nanoparticles as $<200 \mu \mathrm{m}$ [4].

Lipid nanoparticles are defined as nanoparticles with components of the lipid molecule. Lipid-based nanoparticles have some advantages such as their low toxicity for in vivo assay, their ability to improve their physical properties, drug loading efficiency, and drug release potential [5]. Lipid nanoparticle development grew rapidly in the field of nanoparticle technology due to its potential benefits in drug delivery systems, clinical treatment, and research development [6]. The complex of lipid nanoparticles using the ligand of 4-nbutylresorcinol, a derivative of resorcinol compound,

* Corresponding author.

DOI: 10.22146/ijc.28919

Email address : dikaocta@usd.ac.id

Rini Dwiastuti et al. 
can be developed as a drug in the complex form of lipid nanoparticles to improve physical instability characterized by discoloration [7]. The development of lipid nanoparticle technology aims to improve drug encapsulation and reduce leakage of active substances during the storage process [8].

Encapsulation of drugs in complex systems of lipid nanoparticles represents the trapped amount of 4-nbutylrescinol in the lipid nanoparticle system [9]. It is important to determine the drug content in the complex system using an appropriate analytical method [10]. Chromatography, commonly used for this approach, can be used to analyze drug content in complexes or mixtures such as in multivitamins [11], natural products [12], and blood plasma [13]. Especially for the liposome analysis, calculation of EE\% can be performed to determine free drug and is supported by High Performance Liquid Chromatography (HPLC) method [14]. An analytical method of fluorouracil (5-FU) compounds contained in nanoparticle polymers using HPLC method has been developed [15]. Other research has successfully developed HPLC methods for determining the resorcinol [16-17]. Hence, analytical method validation of free drug in complex 4- $n$ butylresorcinol lipid nanoparticles in the lipid nanoparticle system should be performed since it was important to determine the efficiency of encapsulation of drug compounds in formulated lipid nanoparticles system using a validated HPLC method [10].

In this study, a valid RP-HPLC method was developed to determine free drug content of $4-n$ butylresorcinol in the liposome matrix followed by the determination of the EE\%. The analytical method validation was performed for the parameter of selectivity, sensitivity, linearity, accuracy, and precision.

\section{EXPERIMENTAL SECTION}

\section{Materials}

Materials used in this study were: L- $\alpha$ phosphatidylcholine from soy lecithin (pharmaceutical grade, Sigma Aldrich, USA), redistilled water, 4- $n$ butylresorcinol (98.1\%, TCl, Japan), ethanol (analytical grade, Merck, USA), methanol (analytical grade, Merck, USA), and Phosphate Buffer Saline (PBS) (pharmaceutical grade, Biogear, China).

\section{Instrumentation}

The instruments used in this study were glassware (pyrex); hot plate, blender (Waring, America); ultraturax; bath sonicator (Elmasonic, Germany); microcentrifuge (Centurion, UK), micropipette (Socorex), analytical balance (OHAUS (min 0.01), America), analytical balance (Scaltec SBC 22 ( $\min 0.001 \mathrm{~g})$, USA), pH meter (SI Analytics), ultra-purified water (Thermo Scientific, Amerika), particle size analyzer (Horiba SZ100, Japan); transmission electron microscopy (type JEOL JEM-1400, Japan); HPLC with UV detector (Shimadzu LC-2010C, Japan).

\section{Procedure}

\section{Standard solution preparation}

The 4-n-butylresorcinol standard stock solution was prepared as follows: $10.00 \mathrm{mg}$ of $4-n-$ butylresorcinol were accurately weighed into a $10 \mathrm{~mL}$ volumetric flask, dissolved and diluted with ethanol. Calibration standard solution of 4- $n$-butylresorcinol was obtained by preparing 4- $n$-butylresorcinol solution in the series of $5.35,10.7,16.05,21.4,26.75,32.1$, $37.45,42.8,48.15$, and $53.5 \mu \mathrm{g} / \mathrm{mL}$ from the standard stock solution of $4-n$-butylresorcinol in the $10 \mathrm{~mL}$ volumetric flask for each concentration. Three hundred microliters of liposome matrix were added to every volumetric flask before diluting to volume with ethanol.

\section{Chromatographic conditions}

Calibration standard of 4- $n$-butylresorcinol and samples solutions were analyzed using Shimadzu LC2010 HPLC with UV detector. The analytical column was a Phenomenex® $\mathrm{C}_{18}$ column $(250 \times 4.6 \mathrm{~mm}$, $5 \mu \mathrm{m})$. Chromatography was carried out using methanol-redistilled water- glacial acetic acid 79:20:1 $(\mathrm{v} / \mathrm{v})$ as the mobile phase with $\mathrm{pH}$ maintained at 2.12.6. The flow rate of the mobile phase was maintained at $0.8 \mathrm{~mL} / \mathrm{min}$ in the isocratic reverse-phase HPLC system. All the solutions were injected into HPLC system in the volume of $10 \mu \mathrm{L}$ and detected using UV detector at $279 \mathrm{~nm}$.

\section{System suitability test}

System suitability was determined from five replicate injections of the system suitability standard before sample analysis. The acceptance criteria were less than $2 \%$ relative standard deviation (\%RSD) for peak area and retention time, greater than 2000 column plates number, resolution value of more than 2.0, and tailing factor of less than 2.0 [18].

\section{Complex lipid nanoparticle preparation}

Preparation of complex lipid nanoparticle was prepared by dispersing $8.70 \mathrm{~g}$ phospholipid in $100 \mathrm{~mL}$ distilled water [19] with $0.1 \%$ (w/v) 4-n-butylresorcinol [20]. Phospholipids and water were mixed and blended for $60 \mathrm{sec}$. Further, this mixture was subjected to sonication for about $30 \mathrm{~min}$ at temperature $60^{\circ} \mathrm{C}$. In the early sonication process, $4-n$-butylresorcinol was added as the active compound. The complex lipid 
nanoparticles were analyzed using particle size analyzer (PSA) to examine the particle sizes and transmission electron microscopy (TEM) to see the shape of the complex lipid nanoparticle [21].

\section{Analytical method validation for determining free drug content}

Selectivity. The selectivity test solution was obtained by transferring $300 \mu \mathrm{L}$ of sample solutions combined with a a standard solution of 4 - $n$-butylresorcinol at three different concentration levels $(10,15$ and $20 \mu \mathrm{g} / \mathrm{mL})$ into $10 \mathrm{~mL}$ volumetric flask for each concentration and diluted with ethanol. All the solutions were injected into HPLC system in the volume of $10 \mu \mathrm{L}$ and detected using UV detector at $279 \mathrm{~nm}$. The selectivity test was examined by peak profile identification. The resolution value greater than 2 would indicate a good separation to meet the acceptance criteria [22].

Linearity. Linearity test solutions of 4-n-butylresorcinol were prepared from the standard stock solution at eleven different concentration levels $(5-55 \mu \mathrm{g} / \mathrm{mL})$. The calibration curves were constructed by plotting their concentrations versus peak areas. The correlation coefficient, slope, and intercept of the calibration curve were calculated.

Sensitivity. The sensitivity of the method was presented by the value of the limit of detection (LoD) and limit of quantification (LoQ). The LoD and LoQ of 4- $n$ butylresorcinol were determined by using the standard deviation approach as defined in Ahuja \& Dong and Ermer \& Miller [22-23]. A specific calibration curve in the lowest concentration should be studied using samples containing 4- $n$-butylresorcinol. The LoD and LoQ values were calculated by both the residual standard deviation of a calibration curve and the $y$-intercepts of regression lines [24].

Accuracy and precision. The accuracy and precision of the solution were obtained by transferring $300 \mu \mathrm{L}$ of sample solutions combined with a standard solution of 4$n$-butylresorcinol at three different concentration levels $(10,15$ and $20 \mu \mathrm{g} / \mathrm{mL}$ ) into a $10 \mathrm{~mL}$ volumetric flask for each concentration and diluted with ethanol. All the solutions were injected into HPLC system in the volume of $10 \mu \mathrm{L}$ and measured using UV detector at $279 \mathrm{~nm}$. The accuracy and precision of the method were assessed by calculating the recovery and RSD value at three concentration levels (low, medium, high) and three replicates of each concentration.

\section{Determination of free drug content and encapsulation efficiency (EE\%)}

The sample solution was obtained by transferring $500 \mu \mathrm{L}$ of the sample solution into a micro-centrifuge tube and diluting to $1000 \mu \mathrm{L}$ with ethanol. This solution was centrifuged for $30 \mathrm{~min}(15000 \mathrm{rpm})$. Free drug content determination of the model compound 4- $n$ butylresorcinol was performed using a developed HPLC method. The determined content of free 4- $n$ butylresorcinol presented the content of unencapsulated $4-n$-butylresorcinol in the matrix of drug delivery system models within the formulation process. EE\% determination was performed based on analytical data of free drug in the liposome matrix using a developed HPLC method. The calculation EE\% was performed using the formula (1) as described in Chan et al. [25].

$\mathrm{EE} \%=\frac{\text { weight of added analyte }- \text { weight of unencapsulated analyte }}{\text { weight of added analyte }} \times 100 \%$

\section{RESULT AND DISCUSSION}

The complex lipid nanoparticle of 4- $n$ butylresorcinol characteristics profile obtained from this study was presented in Table 1. The particle size of the complex nanoparticle, described as the z-average value was measured in this study as $<200 \mathrm{~nm}$ and met the acceptance criteria [4]. The polydispersity index during the storage time (0-30 days) met the acceptance criteria for the polydisperse nanoparticle system of $<0.3$ [26]. Complex lipid nanoparticles resulting from the heating and sonication method had a particle size similar to the previous study [20]. Morphology of complex lipid nanoparticle from TEM observation was shown in Fig. 1.

The calculation of $\mathrm{EE} \%$ during storage presented the stability of complex lipid nanoparticle 4-nbutylresorcinol as the drug delivery system obtained during the storage. Analytical method validation for determining free drug content in the matrix of complex lipid nanoparticle 4- $n$-butylresorcinol was performed in this study as follows:

\section{System Suitability}

The system suitability test for the HPLC method established was performed to assess the instrument performance parameters such as peak area \%RSD, retention time \%RSD, total plate number, tailing factor of 4- $n$-butylresorcinol peak, and resolution. The mean $(n=5)$ peak area \%RSD was $1.37 \%$, the mean retention time \%RSD was $0.06 \%$, the mean total plate number was 6782.8 , the mean tailing factor was 1.19, and the resolution for 4-n-butylresorcinol and neighboring peak was 6.15 .

\section{Selectivity}

Wavelength detection of $279 \mathrm{~nm}$ was determined by scanning three concentrations of standard solution $(10,20$, and $30 \mu \mathrm{g} / \mathrm{mL})$ at $200-400 \mathrm{~nm}$. Representative 
Table 1. Complex lipid nanoparticle size of 4 - $n$-butylresorcinol

\begin{tabular}{cccc}
\hline \multirow{2}{*}{ Day of storage } & \multirow{2}{*}{ Replication } & \multicolumn{3}{c}{ Nanoparticle size } \\
\cline { 3 - 4 } & & z average $(\mathrm{nm})$ & Polydispersity index $(\mathrm{PI})$ \\
\hline \multirow{2}{*}{0} & 2 & 82.30 & 0.281 \\
& mean & 80.00 & 0.299 \\
\hline \multirow{2}{*}{7} & 1 & 81.15 & 0.212 \\
& 2 & 84.90 & 0.231 \\
\hline \multirow{2}{*}{14} & mean & 81.90 & 0.053 \\
& 2 & 83.40 & 0.245 \\
\hline \multirow{2}{*}{21} & mean & 91.80 & 0.253 \\
& 2 & 84.20 & 0.153 \\
\hline \multirow{2}{*}{30} & mean & 88.00 & 0.221 \\
& 2 & 85.90 & 0.157 \\
\end{tabular}
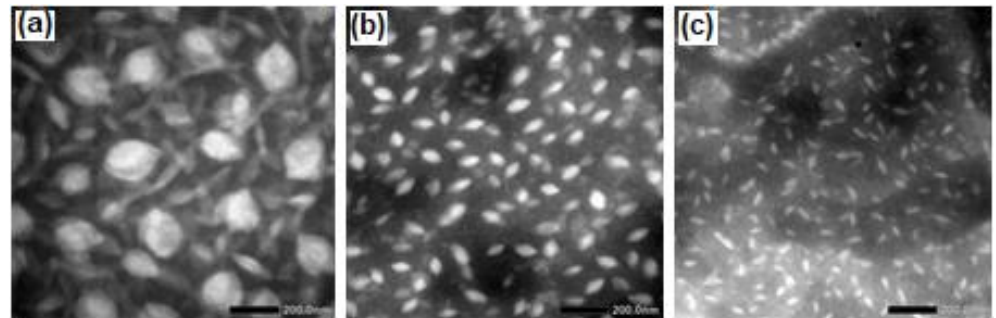

Fig 1. Morphology of complex lipid nanoparticle 4- $n$-butylresorcinol observed using TEM; Observation day-0 (a); Observation day-7 (b); Observation day-14 (c)

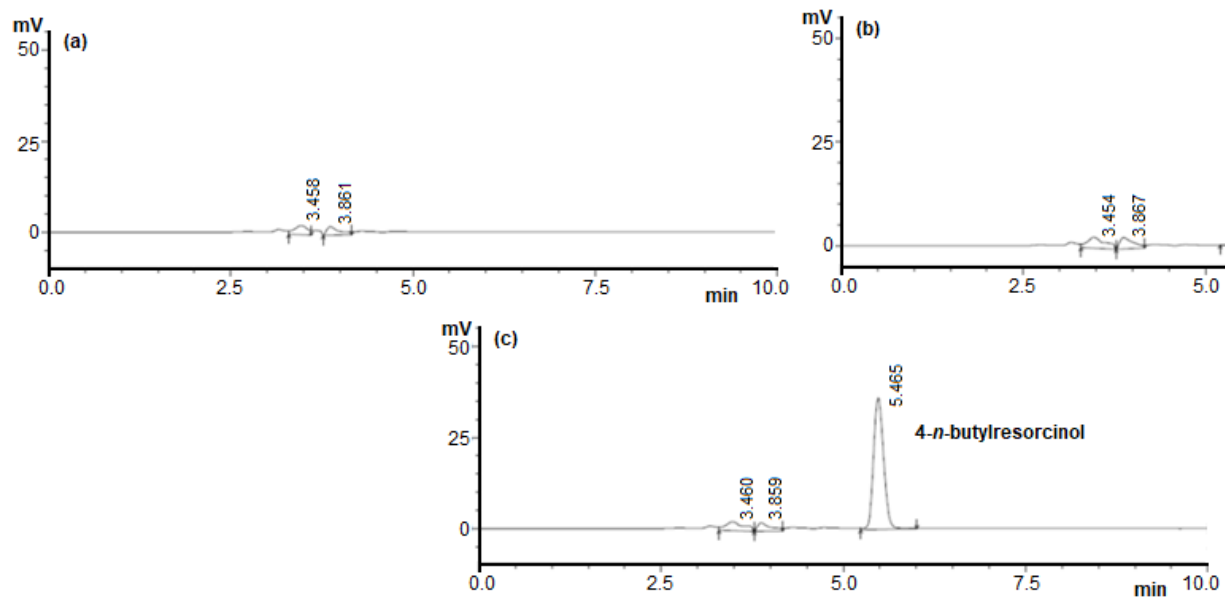

Fig 2. Representative chromatograms of the blank solution (a), standard solution of 4- $n$-butylresorcinol at concentration of $32.1 \mathrm{ug} / \mathrm{mL}(\mathrm{b})$, and sample solution of free drug in the matrix of phosphatidylcholine (c)

chromatogram presented in Fig. 2 showed the good separation of $4-n$-butylresorcinol at the retention time of 5.494 min. Resolution of the major peak was 6.1. The chromatogram separation profile and resolution obtained in this study indicated that chromatogram separation of 4- $n$-butylresorcinol met the acceptance criteria since the resolution value was more than 2 [22].

\section{Linearity}

Linearity parameter was observed in this study from the calibration curves resulting from plotting concentrations versus peak areas of $4-n$-butylresorcinol in the presence of phosphatidylcholine matrix. A series of linearity standard solution $(5-55 \mu \mathrm{g} / \mathrm{mL})$ was injected 
into the HPLC system. The calibration curve equation of 4- $n$-butylresorcinol was obtained using equation of $y=$ $11254 x+3994(r=0.999)$. The calibration standard curve is presented in Fig. 3.

\section{Sensitivity}

The sensitivity of the method was presented by the value of $L O D$ and LoQ resulting from a calculation using the standard deviation approach [22-23]. LoD and LoQ of the method were 1.21 and $4.04 \mu \mathrm{g} / \mathrm{mL}$, respectively.

\section{Precision}

The precision test was performed using the standard addition method. The three levels concentration of 4 - $n$-butylresorcinol were added into the sample matrix and evaluated both intraday and interday as shown in Table 2. The percentage of RSD resulting from each concentration level should not be more than $3.7 \%$ [27]. The required values of percentage RSD were accepted in the low, medium, and high concentration level of 4- $n$-butylresorcinol addition.

\section{Accuracy}

An accuracy test was performed using the standard addition method. The three concentration levels consisted of the low $(10.30 \mu \mathrm{g} / \mathrm{mL})$, medium $(15.45 \mu \mathrm{g} / \mathrm{mL})$, and high $(20.60 \mu \mathrm{g} / \mathrm{mL})$ as shown in Table 3 . The value of the recovery as the accuracy parameter at three concentration levels of 4-nbutylresorcinol were within the required range of 95 $105 \%$ [27].

\section{Determination of Free Drug Content and EE\%}

Free drug content and EE\% were determined in this study. A validated HPLC method has been used to analyze free drug content of the model compound 4- $n$ butylresorcinol and resulted in a good separation (Fig. 2). The EE\% calculation results of $4-n$-butylresorcinol in the phosphatidylcholine matrix were presented in Table 4.

The EE\% calculation was performed to observe the stability profile of complex lipid nanoparticle 4- $n$-butylresorcinol during the storage of day $0,7,14$, 21 , and 30 . The EE\% increased during storage. The

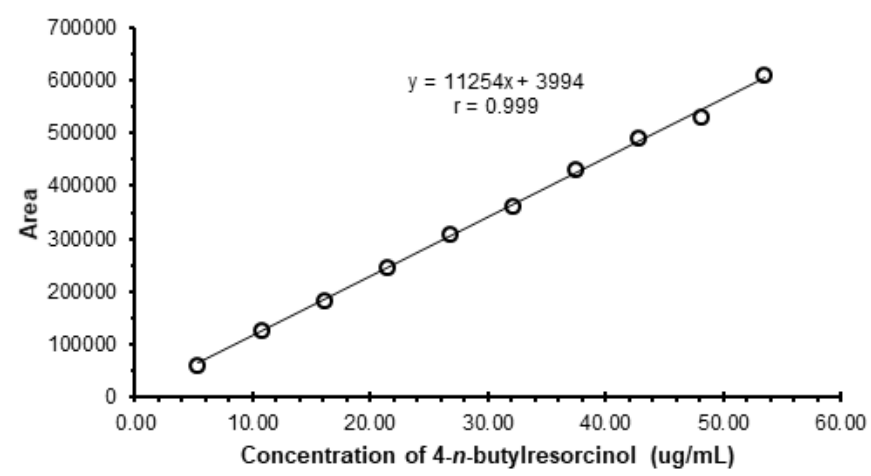

Fig 3. Calibration curve of 4-n-butylresorcinol

Table 2. Precision test of 4- $n$-butylresorcinol in the complex lipid nanoparticle

\begin{tabular}{cccc}
\hline $\begin{array}{c}\text { Level of standard } \\
\text { addition }\end{array}$ & $\begin{array}{c}\text { Concentration } \\
\text { added }(\mu \mathrm{g} / \mathrm{mL})\end{array}$ & $\begin{array}{c}\text { Amount detected } \\
(\mu \mathrm{g} / \mathrm{mL})(\mathrm{n}=3)\end{array}$ & $\mathrm{RSD}(\mathrm{n}=3)$ \\
\hline Low day 1 & & 10.22 & 0.15 \\
Low day 2 & 10.30 & 10.28 & \\
Low day 3 & & 10.77 & \\
Mean low & & $10.42 \pm 0.30$ & 0.13 \\
\hline Medium day 1 & 15.45 & 14.90 & \\
Medium day 2 & & 15.94 & 0.10 \\
Medium day 3 & & 15.93 & \\
Mean medium & & $15.59 \pm 0.60$ & \\
\hline High day 1 & 20.60 & 20.25 & \\
High day 2 & & 21.40 & \\
High day 3 & & 21.24 & \\
Mean high & & $20.96 \pm 0.62$ & \\
\hline Note: Concentration of 4- $n$-butylresorcinol in the complex lipid nanoparticle without addition \\
was 28.90 $\pm 0.208 \mu \mathrm{g} / \mathrm{mL}(\mathrm{n}=3)$
\end{tabular}

Table 3. Accuracy test of 4-n-butylresorcinol in the complex lipid nanoparticle. Concentration of 4-n-butylresorcinol without standard addition was $28.77 \mu \mathrm{g} / \mathrm{mL}$

\begin{tabular}{cccc}
\hline $\begin{array}{c}\text { Level of standard } \\
\text { addition }\end{array}$ & $\begin{array}{c}\text { Concentration } \\
\text { added }(\mu \mathrm{g} / \mathrm{mL})\end{array}$ & $\begin{array}{c}\text { Amount detected } \\
(\mu \mathrm{g} / \mathrm{mL})(\mathrm{n}=3)\end{array}$ & $\begin{array}{c}\text { Recovery } \\
(\%)\end{array}$ \\
\hline Low & 10.30 & 10.35 & 101.18 \\
Medium & 15.45 & 15.03 & 100.91 \\
High & 20.60 & 20.38 & 101.70 \\
\hline
\end{tabular}


Table 4. Determination of free drug content and EE\% during the storage

\begin{tabular}{rcc}
\hline Day & $\begin{array}{c}\text { Free drug content of } 4-n- \\
\text { butylresorcinol }(\mathrm{ug} / \mathrm{mL})\end{array}$ & $\mathrm{EE} \%( \pm \mathrm{SD})$ \\
\hline 0 & 772.37 & $22.76( \pm 3.69)$ \\
7 & 762.84 & $23.72( \pm 4.06)$ \\
14 & 684.85 & $31.52( \pm 0.81)$ \\
21 & 539.51 & $46.05( \pm 36.07)$ \\
30 & 262.49 & $48.75( \pm 37.28)$ \\
\hline
\end{tabular}

aggregation formation of complex lipid nanoparticle 4- $n$ butylresorcinol during storage resulted in a bigger complex and enabled the drug to trap inside. The aggregation phenomenon forming the bigger complex of lipid nanoparticle 4- $n$-butylresorcinol might decrease the free drug in the system. However, EE\% was increased during storage. The previous study [28] brought forth the insight of a new hypothesis that the decrease of EE\% was correlated with the increase of the drug versus lipid ratio. The EE\% was significantly affected by the alteration of the drug versus lipid ratio.

\section{CONCLUSION}

The method used in this research was validated in the parameter of selectivity (6.1), sensitivity (LoD and LoQ of the method were 1.21 and $4.04 \mu \mathrm{g} / \mathrm{mL}$ ), linearity (0.999), accuracy (100.91-101.77), and precision (0.100.15). During 30 days of storage, the complex lipid nanoparticle system showed an increase in the EE\% value.

\section{ACKNOWLEDGEMENT}

This research was financially supported by "Sanata Dharma" Foundation (Grant No. K-1160/Yys/315/IX/2013 to Rini Dwiastuti) and Indonesian Directorate General of Higher Education (BPPDN Program No. 1251.15/E4.4/2012 to Rini Dwiastuti). We thank Dina Christin Ayuning Putri for the laboratory technical assistant.

\section{REFERENCES}

[1] Buzea, C., Pacheco I.I., and Robbie, K., 2007, Nanomaterials and nanoparticles: sources and toxicity nanomaterials and nanoparticles: Sources and toxicity, Biointerphases, 2 (4), MR17-MR71.

[2] Martien, R., Adhyatmika, Irianto, I.D.K., Farida, V., and Sari, D.P., 2012, Perkembangan teknologi nanopartikel sebagai sistem penghantaran obat, Majalah Farmaseutik, 8 (1), 133-144.

[3] Potocnik, J., 2011, Commission recommendation of 18 October 2011 on the definition of nanomaterial, Off. J. Eur. Union, L275, 38-40.
[4] Reverchon, E., and Adami, R., 2006, Nanomaterials and supercritical fluids, J. Supercrit. Fluids, 37 (1), 1-22.

[5] Puri, A., Loomis, K., Smith, B., Lee, J.H., Yavlovich, A., Heldman, E., and Blumenthal, R., 2009, Lipid-based nanoparticles as pharmaceutical drug carriers: From concepts to clinic, Crit. Rev. Ther. Drug Carrier Syst., 26 (6), 523-580.

[6] Attama, A.A., Momoh, M.A., and Builders, P.F., 2012, "Lipid Nanoparticulate Drug Delivery Systems: A Revolution in Dosage Form Design and Development" in Recent Advance in Novel Drug Carrrier Systems, Demir, A., eds., InTech, DOI: $10.5572 / 50486$.

[7] Love, A.R., Kerschner, J.L., Barratt, M.J., and Zhou, Y., 2003, Stabilization of resorcinol derivatives in cosmetic compositions, U.S. Patent, $0180234 \mathrm{~A} 1$.

[8] Toh, M.R., and Chiu, G.N.C., 2013, Liposomes as sterile preparations and limitations of sterilisation techniques in liposomal manufacturing, Asian $\mathrm{J}$. Pharm. Sci., 8 (2), 88-95.

[9] Chang, H.I., and Yeh, M.K., 2012, Clinical development of liposome-based drugs: Formulation, characterization, and therapeutic efficacy, Int. J. Nanomed., 7, 49-60.

[10] Jeschek, D., Lhota, G., Wallner, J., and VorauerUhl, K., 2016, A versatile, quantitative analytical method for pharmaceutical relevant lipids in drug delivery systems, J. Pharm. Biomed. Anal., 119, 37-44.

[11] Riswanto, F.D.O., Lukitaningsih, R.R.E., and Martono, S., 2015, Analytical method validation and determination of pyridoxine, nicotinamide, and caffeine in energy drinks using thin layer chromatography-densitometry, Indones. J. Chem., 15 (1), 9-15.

[12] Syukri, Y., Martien, R., Lukitaningsih, E., and Nugroho, A.E., 2016, Quantification of andrographolide isolated from Andrographis paniculata nees obtained from traditional market in Yogyakarta using validated HPLC, Indones. J. Chem., 16 (2),190-197.

[13] Suchocka, Z., Gronostajska, D., Suchocki, P., and Pachecka, J., 2003, New HPLC method for separation of blood plasma phospholipids, $J$. Pharm. Biomed. Anal., 32 (4-5), 859-865.

[14] Chimanuka, B., Gabriëls, M., Detaevernier, M.R., and Plaizier-Vercammen, J.A., 2002, Preparation of $\beta$-artemether liposomes, their HPLC-UV evaluation and relevance for clearing recrudescent parasitaemia in Plasmodium chabaudi malariainfected mice, J. Pharm. Biomed. Anal., 28 (1), 13-22. 
[15] de Mattos, A.C., Khalil, N.M., and Mainardes, R.M., 2013, Development and validation of an HPLC method for the determination of fluorouracil in polymeric nanoparticles, Braz. J. Pharm. Sci., 49 (1), 117-126.

[16] De, A.K., Chowdhury, P.P., and Chattapadhyay, S., 2014, Quantitative analysis of resorcinol from marketed hair tonic using liquid chromatographic technique, Int. Sch. Res. Notices, 2014, 632591.

[17] De, A.K., Chowdhury, P.P., and Chattapadhyay, S., 2016, Simultaneous quantification of dexpanthenol and resorcinol from hair care formulation using liquid chromatography: Method development and validation, Scientifica, 2016, 1537952.

[18] Snyder, L.R., Kirkland, J.J., and Dolan, J.W., 2010, Introduction to Modern Liquid Chromatography, $3^{\text {rd }}$ ed., John Wiley \& Sons, Inc., New Jersey.

[19] Dwiastuti, R., Radifar, M., Marchaban, Noegrohati, S., and Istyastono, E.P., 2016, Molecular dynamics simulations and empirical observations on soy lecithin liposome preparation, Indones. J. Chem., 16 (2), 222-228.

[20] Dwiastuti, R., Noegrohati, S., and Istyastono, E.P., 2016, Formulation and physical properties observations of soy lecithin liposome containing 4n-butylresorcinol, AIP Conf. Proc., 1755 (1), 160005.

[21] Badran, M., Shalaby, K., and Al-Omrani, A., 2012, Influence of the flexible liposomes on the skin deposition of a hydrophilic model drug, carboxyfluorescein: Dependency on their composition, Sci. World J., 2012, 134876.

[22] Ermer, J., and Miller, J., 2005, Method validation in pharmaceutical analysis. A Guide to best Practice, Wiley-VCH Verlag GmbH \& Co. KGaA, Weinheim.

[23] Ahuja, S., and Dong, M.W., 2005, Handbook of Pharmaceutical Analysis by HPLC, vol. 6, $1^{\text {st }}$ ed., Elsevier Academic Press, London.

[24] Şengül, U., 2015, Comparing determination methods of detection and quantification limits for aflatoxin analysis in hazelnut, J. Food Drug Anal., 24 (1), 56-62.

[25] Chan, Y.H., Chen, B.H., Chiu, C.P., and Lu, Y.F., 2004, The influence of phytosterols on the encapsulation efficiency of cholesterol liposomes, Int. J. Food Sci. Technol., 39 (9), 985-995.

[26] MalvernTech, 2012, Guide to dynamic light scattering measurement and analysis, NanoComposix, v1.3, 1-7.

[27] González, A.G., and Herrador, M.Á., 2007, A practical guide to analytical method validation, including measurement uncertainty and accuracy profiles, TrAC, Trends Anal. Chem., 26 (3), 227238.

[28] Liu, X., Ruan, L., Mao, W., Wang, J., Shen, Y., and Sui, M., 2010, Preparation of RGD-modified long circulating liposome loading matrine, and its in vitro anti-cancer effects, Int. J. Med. Sci., 7 (4), 197-208. 